\title{
Triggers For Stock Prices In Manufacturing Companies In The Food and Beverages Sector On The Indonesia Stock Exchange
}

\author{
Ni Nyoman Juli Nuryani ${ }^{1 *}$ \\ ${ }^{1}$ Sekolah Tinggi Ilmu Ekonomi Satya Dharma, Singaraja, Indonesia
}

\section{ARTICLE INFO}

\section{Article history:}

Received September 19, 2021

Revised September 20, 2021

Accepted October 30, 2021

Available online November 25, 2021

Keywords:

Stock Price, Manufacturing

Company, Stock Exchange

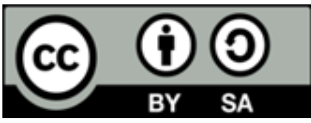

This is an open access article under the CC BY-SA license.

Copyright $(2021$ by Author. Published by Universitas Pendidikan Ganesha.

\begin{abstract}
A B S T R A C T
The global economy was sluggish due to the COVID-19 pandemic. Until March 2020, the economy began to decline, along with the pandemic outbreak throughout the world, including in Indonesia. People lost jobs due to the weakening of the national economy. This study aims to analyze the effect of Earning per Share (EPS) Net Profit Margin (NPM), Gross Profit Margin (GPM) Total Assets Turnover (TATO), and Total Assets Turnover (TATO) on company stock prices in manufacturing in the food and beverage sector. It was listed on the Indonesia Stock Exchange (IDX) with an observation period of 2016-2021. The population and sample in this study are the quarterly financial reports of manufacturing companies in the food and beverage sector listed on the Indonesia Stock Exchange. The sampling method used is the purposive sampling method, with a total sample of 252 quarterly financial statements taken from 12 companies. The data used in this research is secondary data. Furthermore, the data collected was tested by multiple linear regression analysis, processed using the SPSS version 18 application. The results showed that partially EPS and NPM had a positive and significant effect on stock prices, while GPM had no significant effect on stock prices, and TATO had a negative effect. And significant to stock prices. Simultaneously, EPS, NPM, GPM, and TATO have a positive and significant effect on stock prices with a coefficient of determination of $67.4 \%$.
\end{abstract}

\section{INTRODUCTION}

The global economy, including Indonesia, which had been sluggish due to the COVID-19 pandemic, began to show a positive stretch with a number of adjustments (Hart \& Halden, 2020; Ibn-Mohammed et al., 2021). Last December 2019, when the COVID-19 pandemic first appeared in Wuhan, China, the world economy was still in an optimistic position (Handayani et al., 2020; Lyócsa et al., 2020; Shah et al., 2020). However, around mid-March 2020, the economy began to decline, along with the spread of the pandemic throughout the world, including in Indonesia (Maulana, 2021; Prawiyogi et al., 2020; Yulia, 2020). Where many people lose their income and also their jobs as a result of the weakening national economy (Indayani \& Hartono, 2020; Paramita \& Putra, 2020). Loss of income greatly affects people's difficulties in meeting their daily needs. Under these conditions, investment becomes very important because investment can be used as an alternative to earn additional income beyond the monthly salary so that daily needs can be met (Giofré, 2021; Tarkom, 2020). One of the investment alternatives that investors are interested in is investing in shares (Hongkong, 2017). Stocks are known to have the characteristics of high risk-high return. This means that stocks are a type of investment that is quite high risk even though it promises relatively large profits. In investing in stocks, stock prices are an important factor and must be considered by investors because the price of shares traded on the stock exchange is closely related to the achievements of the company (Luo, 2021; Wang et al., 2021).

Fundamental analysis is an analysis that tries to estimate stock prices in the future by estimating the value of fundamental factors that affect stock prices in the future and applying the relationship between these variables to obtain an estimated stock price (Ghosh et al., 2021; Wei et al., 2019). The fundamental factors that affect stock prices are micro fundamentals (sales and company financial performance) and macro fundamental factors (government policies, inflation, interest rate growth, and so on (Lubis et al., 2021; Ma, 2020). In this study, micro factors will be discussed from aspects of the company's financial performance as measured using financial ratios. The company's financial performance that can affect stock prices include Earning per Share (EPS), Net Profit Margin (NPM), Gross Profit Margin (GPM), and Total Asset 
Turnover (TATO). Earning Per Share (EPS) is the company's ability to distribute the profits earned by the company to shareholders (Jiang et al., 2021; Zheng \& He, 2021). Earnings per share can be used as important information for investors. A high EPS indicates that the company can provide a level of profit to shareholders, whereas a lower EPS provides a low level of profit to shareholders. EPS describes the amount of rupiah earned for each share of common stock and the company's earnings prospects in the future. An increase in EPS will encourage investors to increase the amount of capital invested in the company, so that the demand for these shares increases which results in an increase in share prices (Brown et al., 2019; J. Chen et al., 2020).

Net Profit Margin is a ratio used to measure the percentage of net profit on net sales (FernandezPerez et al., 2021a; Le et al., 2020). The higher the NPM value, the better, high profits will attract investors to invest, which causes stock prices to increase. This ratio is very important for operations managers because it reflects the company's sales pricing strategy and its ability to control operating expenses. The greater the NPM, the more productive the company's performance will be, so that it will increase investor confidence to invest in the company (Bilal \& Oyedele, 2020; Fernandez-Perez et al., 2021a; Le et al., 2020). Gross Profit Margin shows the profit relative to the company, by means of net sales minus cost of goods sold. This ratio is a way to apply the cost of goods sold. A high GPM value indicates the company's ability to generate profits at a certain level of sales. The higher the GPM, the higher the profit or profit generated by the company, this can increase investor confidence in the company, in the end it will increase stock prices and vice versa (Jiang et al., 2021; Zheng \& He, 2021).

Total Asset Turnover (TATO) is a ratio used to see the extent to which a company's ability to create sales uses all its assets (T.-Y. Chen et al., 2021; Parlindungan et al., 2019). Good asset turnover is asset turnover that increases every year. Increased asset turnover means that the company is able to manage assets well which results in high sales (Y. Chen, 2021; Fang et al., 2021). Conversely, if asset turnover tends to be small, this indicates that the company is not able to manage assets to generate sales (Maciel, 2021; Sari, 2020). A high TATO value indicates performance. In this study, one sector of the company that is included in the Consumer Goods Industry category is selected which is listed on the Indonesia Stock Exchange. Companies that fall into this category are stable companies despite the global crisis. This can be seen from the company's stock price index, which is one of the five sectoral indexes on the Indonesia Stock Exchange which has a fairly high stock price level. However, fluctuating economic conditions resulted in instability in the company's financial performance and stock prices. The financial performance and stock prices experienced by manufacturing companies in the food and beverages sector experienced fluctuations from 2016-2020. This can be seen in the first company's financial ratio, namely EPS, which initially in 2016 obtained a value of Rp. 228.69. Then, in 2017 there was a significant decrease of Rp. 206.40. And from 2018 to 2019, EPS has increased in succession, but in 2020, EPS has again decreased by Rp. 269.33. Next is the financial ratio of NPM and GPM. Both ratios experience the same upward and downward trend. Where from 2016-2018 NPM and GPM showed stable values, namely 0.12 and 0.36 . A company is in good condition so that it is able to attract investors to buy shares. This study aims to analyze the effect of Earning per Share (EPS) Net Profit Margin (NPM), Gross Profit Margin (GPM) Total Assets Turnover (TATO), and Total Assets Turnover (TATO) on company stock prices in manufacturing in the food and beverage sector.

\section{METHODS}

This study uses empirical data obtained from the Indonesia Stock Exchange (www.idx.co.id) which focuses on manufacturing companies in the food and beverage sector listed on the Indonesia Stock Exchange. The data taken from the research is data from 2016 to 2021. The reason for choosing the location of this research is that the researcher wants to re-examine the variables that can affect stock prices. This is because in previous studies, it was found that there are still many differences in research results related to variables that can affect stock prices. The type of data used in this study consists of quantitative data, namely stock price data and financial reports for the first quarter to fourth quarter of manufacturing companies in the food and beverages sector for the 2016-2021 period. A sample of 252 quarterly financial reports from 12 manufacturing companies in the food and beverage sector listed on the Indonesia Stock Exchange (IDX).

The data collection technique in this study is a documentation technique. This study uses secondary data in the form of documents and written information related to the object of research obtained from www.idx.co.id. The population is a generalization area consisting of objects/subjects that have certain qualities and characteristics determined by researchers to be studied and then drawn conclusions (Sugiyono, 2019). The population in this study was 546 financial statements for the 2016-2021 quarter from 26 manufacturing companies in the food and beverages sector on the Indonesia Stock Exchange. The sample is part of the number and characteristics possessed by the population. In this study using purposive sampling. The data analysis technique used is multiple linear regression analysis. 


\section{RESULTS AND DISCUSSIONS}

\section{Results}

This study uses a sample of 252 quarterly financial statements obtained from 12 manufacturing companies in the food and beverages sector listed on the Indonesia Stock Exchange for 5 years and 3 months (2016-2021 period). The initial stage of the analysis process in this study is to determine in advance the results of Earning Per Share (EPS), Net Profit Margin (NPM), Gross Profit Margin (GPM), Total Asset Turnover (TATO) and share price per manufacturing company. Meanwhile, in data processing, SPSS program assistance was used to test the hypothesis between EPS, NPM, GPM, and TATO on stock prices.

Table 2. Results of Multiple Linear Analysis

\begin{tabular}{|c|c|c|c|}
\hline \multirow[t]{2}{*}{ Model } & \multicolumn{2}{|c|}{ Unstandardized Coefficients } & \multirow{2}{*}{$\begin{array}{l}\text { Standardized } \\
\text { Coefficients } \\
\text { Beta }\end{array}$} \\
\hline & $B$ & Std. Error & \\
\hline (Constant) & 19.896 & 7.413 & \\
\hline EPS & 3.728 & 0.250 & 0.707 \\
\hline NPM & 37.348 & 14.894 & 0.157 \\
\hline GPM & 15.306 & 11.633 & 0.074 \\
\hline TATO & -26.727 & 5.261 & -0.220 \\
\hline
\end{tabular}

The following describes the interpretation of the multiple linear regression equation from the above equation model. First, from the multiple linear regression equation above, it can be seen that the constant value for the stock price is 19.896. This means that if EPS, NPM, GPM, and TATO are constant, then the stock price is 19.896. Second, the effect of EPS (X1) on stock prices (Y) from the multiple linear regression equation above, it can be seen that the regression coefficient of the EPS variable is 3.728 and is positive, which means that if there is an increase in EPS by one unit, it will cause an increase in the price. shares of 3,728. Third, the effect of NPM (X2) on stock prices (Y), from the multiple linear regression equation above, it can be seen that the regression coefficient of the NPM variable is 37.348 and is marked and has a positive sign, which means that if there is an increase in NPM by one unit, it will led to an increase in share prices by 37,348. positive which means that if there is an increase in NPM by one unit, it will cause an increase in share prices by 37.348. Fourth, the effect of GPM (X3) on stock prices (Y), from the multiple linear regression equation above, it can be seen that the regression coefficient of the GPM variable is 15.306 and is positive, which means that if there is an increase in GPM by one unit, it will cause an increase in GPM. share price of 15,306. Fifth, the effect of TATO (X4) on stock prices (Y), from the multiple linear regression equation above, it can be seen that the regression coefficient of the TATO variable is $-26,727$ and is negative, which means that if there is an increase in TATO by one unit, it will cause decrease in share price by 26,727 .

Based on the tests that have been carried out, the resulting R2 value is 0.674 or $67.4 \%$. This figure explains that stock prices in food and beverage manufacturing companies listed on the Indonesia Stock Exchange are influenced by Earning Per Share (EPS), Net Profit Margin (NPM), Gross Profit Margin (GPM), and Total Asset Turnover (TATO). ) as much as $67.4 \%$, while the remaining $32.6 \%$ is influenced by other variables not examined in this study. Based on the results of calculations using the SPSS program, the results show that the Fcount value is 127.783 > Ftable, which is 2.408 with a Sig value. of 0.000 which is smaller than the significance value of 0.05 . Thus it can be concluded that simultaneously EPS, NPM, GPM, and TATO have a positive and significant effect on stock prices. From the results of the test that has been carried out, the results obtained regarding the effect of each independent variable on stock prices partially as follows: The first result is the effect of Earning Per Share (EPS) on stock prices. The results of this study indicate that there is a positive and significant effect between EPS and stock prices in food and beverages sector manufacturing companies listed on the Indonesia Stock Exchange. There is a positive and significant effect between EPS on stock prices as indicated by the tcount value of 14.926, which is greater than ttable of 1.651 with a regression coefficient of 3.728 (positive effect). And the value of Sig. of 0.000 is smaller than the significance level of 0.05 (Significant). These results indicate that the greater the value of Earning Per Share (EPS), the higher the company's stock price, on the contrary, the smaller the EPS value, the lower the stock price of manufacturing companies in the food and beverages sector listed on the Indonesia Stock Exchange.

The second result, the influence of Net Profit Margin (NPM) on stock prices. The results of this study indicate that there is a positive and significant effect between NPM and stock prices in food and beverages sector manufacturing companies listed on the Indonesia Stock Exchange. There is a positive and significant effect between NPM on stock prices, indicated by the tcount value of 2,508, which is greater than ttable of 1,651 with a regression coefficient value of 37.348 (positive effect). And the value of Sig. is 0.013 which is 
smaller than the significance level of 0.05 (significant). These results indicate that the value of NPM has a directly proportional relationship with stock prices.

The third result, the effect of Gross Profit Margin (GPM) on stock prices. The results of this study indicate that the Gross Profit Margin (GPM) variable has no significant effect on stock prices in food and beverage manufacturing companies listed on the Indonesia Stock Exchange. This can be shown from the tcount value of 1.316, smaller ttable of 1.651 with a regression coefficient value of 15.306 (no effect). And the value of Sig. of 0.189 , which is greater than the significance level of 0.05 (not significant). Thus, it can be said that there is no significant effect between GPM on stock prices. The results of this study indicate that the Total Asset Turnover (TATO) variable has a negative and significant effect on stock prices in manufacturing companies in the food and beverage sector listed on the Indonesia Stock Exchange. This can be shown from the tcount value of 5.080 which is greater than ttable of 1.651 with the regression coefficient of the TATO variable is -26.727 (negative effect) and has a Sig value. of 0.000 , which is the value of Sig. This is smaller than the 0.05 (significant) level of significance. It can be said that there is a negative and significant effect between TATO on stock prices.

\section{Discussion}

The results of this study support research state that Earning per Share (EPS) has a positive and significant effect on stock prices (Alifatussalimah \& Sujud, 2020; Gustmainar et al., 2018). From the results of the study, EPS has a positive and significant effect on stock prices, indicating that Earning per share (EPS) is a picture of the company in obtaining company profits. The higher the company's profit, the higher the value of EPS owned by the company (Fathonah \& Khanifah, 2013; Kusuma, 2016). Increasing EPS will cause the offer of company shares to increase which will have an impact on increasing dividends and stock prices (Edi, 2016; Efrizon, 2019). From the results of descriptive analysis, the EPS variable shows that the value of earnings for ordinary shares often fluctuates while the number of outstanding shares tends to be constant. The increase or decrease in EPS from year to year is an important measure to determine whether or not the company's performance is good in carrying out operational activities. This change in EPS value helps investors predict future dividend flows. A high EPS indicates that the company can provide a level of prosperity to shareholders.

This study shows that the value of NPM has a directly proportional relationship with stock prices. If the NPM value increases, the stock price will also increase. The results of this study support previous research, which states that NPM has a positive and significant effect on stock price (Dewi \& Solihin, 2020; Rimbani, 2016). The results of hypothesis testing indicate that NPM has a positive and significant effect on stock prices. This has emphasized the importance of the company to manage the company's profits to control the Net Profit Margin as a reference for increasing stock prices (Dewi \& Solihin, 2020; FernandezPerez et al., 2021a). Increasing the Net Profit Margin can be done by increasing profits or reducing operational costs and the company must control the percentage increase in sales that cannot be lower than the percentage increase in costs so that the company's profit will continue to increase. High Net Profit Margin indicates the company's ability to generate high profits at a certain level of sales. The greater the NPM shows the company's productive performance to obtain high profits through a certain level of sales and the company's good ability to reduce operational costs. This increases investor confidence to invest their capital in the company so that the demand for company shares increases which will automatically be followed by an increase in the share price.

The third result, the effect of Gross Profit Margin (GPM) on stock prices. This study indicates that the Gross Profit Margin (GPM) variable has no significant effect on stock prices in food and beverage manufacturing companies listed on the Indonesia Stock Exchange. It means that a company's level of Gross Profit Margin (GPM) does not affect the increase or decrease in stock prices. Previous research also stated that GPM has no significant effect on stock prices (Maciel, 2021; Sari, 2020). Testing the third alternative hypothesis (H3) which is suspected to have a positive influence between the GPM variable on stock prices is not in accordance with this test. There is no effect of GPM on stock prices because the company is less than optimal in maximizing sales in generating gross profit. Thus, the high and low level of Gross Profit Margin (GPM) of a company does not affect the stock price. Thus, investors cannot use GPM as a reference to measure the company's overall profitability (Fernandez-Perez et al., 2021b; Gustmainar et al., 2018). Thus, the high and low level of a company's GPM does not affect investors' expectations of the company. Thus, GPM partially has no significant effect on stock prices.

The last result, the effect of Total Asset Turnover (TATO) on stock prices. The results of this study indicate that the Total Asset Turnover (TATO) variable has a negative and significant effect on stock prices in manufacturing companies in the food and beverage sector listed on the Indonesia Stock Exchange. This means that there is an inverse relationship between TATO and stock prices. Where if the value of the TATO decreases, the stock price will increase significantly (very meaningful). The results of this study support 
the research state that TATO has a negative and significant effect on stock prices (Kusuma, 2016; Parlindungan et al., 2019). The TATO variable in this study reads that TATO has a negative and significant effect on stock prices. That is, a decreased TATO affects the increase in stock prices. The reaction from investors means that investors are still willing to buy shares or maintain their shares even though the TATO has decreased or the percentage is below $100 \%$. The reaction of investors indicates that the shares purchased are classified as defensive stocks. Defensive stocks are stocks that tend to be more stable in times of recession or economic uncertainty in terms of dividends, earnings, and market performance. The food and beverage company category is a stock that falls into the category of defensive stock. Products sold by food and beverage companies are products that are needed by the public, because the products sold are basic necessities, investors assume that they are still willing to buy shares or maintain shares in the company even though the TATO ratio is below $100 \%$.

\section{CONCLUSION}

The first test of Earning Per Share (EPS) has a positive and significant effect on stock prices in manufacturing companies in the food and beverage sector listed on the Indonesia Stock Exchange. The second test of Net Profit Margin (NPM) has a positive and significant effect on stock prices in manufacturing companies in the food and beverage sector listed on the Indonesia Stock Exchange. The third test Gross Profit Margin (GPM) has no significant effect on stock prices in manufacturing companies in the food and beverage sector listed on the Stock Exchange. In Indonesia, the fourth test of Total Asset Turnover (TATO) has a negative and significant effect on stock prices in food and beverage manufacturing companies listed on the Indonesia Stock Exchange. The fifth test of Earning Per Share (EPS) Variables, Net Profit Margin (NPM), Gross Profit Margin (GPM), and Total Asset Turno ver (TATO) simultaneously has a positive and significant effect on stock prices in food and beverage sector manufacturing companies listed on the Indonesia Stock Exchange.

\section{REFERENCES}

Alifatussalimah, \& Sujud, A. (2020). Pengaruh ROA, NPM, DER, Dan EPS Terhadap Harga Saham Perusahaan Subsektor Perkebunan Di Bursa Efek Indonesia. Oikonomia: Jurnal Management, 16(2). https://doi.org/10.47313/oikonomia.v16i2.1142.

Bilal, M., \& Oyedele, L. O. (2020). Guidelines for applied machine learning in construction industry-A case of profit margins estimation. Advanced Engineering Informatics, 43. https://doi.org/10.1016/j.aei.2019.101013.

Brown, S., Dutordoir, M., Veld, C., \& Veld-Merkoulova, Y. (2019). What is the role of institutional investors in corporate capital structure decisions? A survey analysis. Journal of Corporate Finance, 58. https://doi.org/10.1016/j.jcorpfin.2019.05.001.

Chen, J., Tian, G., \& Yang, F. (2020). Individual investors' propensity to speculate and A-share premiums in China's A-shares and H-shares. Emerging Markets Review, 43. https: //doi.org/10.1016/j.ememar.2020.100689.

Chen, T.-Y., Chao, C.-H., \& Wu, Z.-X. (2021). Does the turnover effect matter in emerging markets? Evidence from China. Pacific-Basin Finance Journal, 67. https://doi.org/10.1016/j.pacfin.2021.101551.

Chen, Y. (2021). Does political turnover affect corporate investment? Evidence from China. Emerging Markets Review. https://doi.org/10.1016/j.ememar.2021.100865.

Dewi, I. K., \& Solihin, D. (2020). Pengaruh Current Ratio dan Net Profit Margin Terhadap Harga Saham pada Perusahaan Makanan dan Minuman Yang Terdaftar di Bursa Efek Indonesia (BEI) Periode 20152018. Jurnal Ilmiah Feasible, 2(2). https://doi.org/10.32493/fb.v2i2.2020.183-191.6231.

Edi, E. (2016). Analisis Akuisisi Terhadap Kinerja Keuangan Perusahaan Pengakuisisi Dan Diakuisisi Terdaftar Di Bursa Efek Indonesia. Jurnal Benefita Ekonomi Pembangunan, Manajemen Bisnis Dan Akuntansi, 1(3). https://doi.org/10.22216/jbe.v1i3.1434.

Efrizon, E. (2019). Pengaruh Rasio Keuangan Terhadap Harga Saham Perusahaan Otomotif Periode 20132017. Jurnal Akuntansi Aktua, 6(1). https://doi.org/10.17977/um004v5i32019p250.

Fang, R., Gao, B., \& Hu, N. (2021). Intangible asset value of employee satisfaction in high-contact services. International Journal of Hospitality Management, 94. https://doi.org/10.1016/j.ijhm.2020.102810

Fathonah, S., \& Khanifah, K. (2013). Earning Per Share (Eps), Dan Right Issue Terhadap Return Saham Pada Perusahaan Yang Terdaftar Di Bursa Efek Indonesia Periode 2011. Jurnal Analisis Bisnis Ekonomi, 11(1).

Fernandez-Perez, A., Frijns, B., Gafiatullina, I., \& Tourani-Rad, A. (2021a). Profit margin hedging in the New Zealand dairy farming industry. Journal of Commodity Markets, 26. 
https://doi.org/10.1016/j.jcomm.2021.100197.

Fernandez-Perez, A., Frijns, B., Gafiatullina, I., \& Tourani-Rad, A. (2021b). Profit margin hedging in the New Zealand dairy farming industry. Journal of Commodity Markets. https: //doi.org/10.1016/j.jcomm.2021.100197.

Ghosh, I., Chaudhuri, T. D., Alfaro-Cortés, E., Martínez, M. G., \& Rubio, N. G. (2021). Estimating the relative effects of raw material prices, sectoral outlook and market sentiment on stock prices. Resources Policy, 73. https://doi.org/10.1016/j.resourpol.2021.102158.

Giofré, M. (2021). COVID-19 stringency measures and foreign investment: An early assessment. The North American Journal of Economics and Finance, 58. https://doi.org/10.1016/j.najef.2021.101536.

Gustmainar, Jojor, \& Mariani. (2018). Analysis Of The Effect Of Current Ratio, Debt To Equity Ratio, Gross Profit Margin, Return On Investment, And Earning Per Share On Stock Prices At LQ 45 Companies Listed On The Indonesia Stock Exchange In The Year Of 2010-2016. Bilancia: Jurnal Ilmiah Akuntansi, 2(4).

Handayani, D., Hadi, D. R., Isbaniah, F., Burhan, E., \& Agustin, H. (2020). Corona virus disease 2019. Jurnal Respirologi Indonesia, 40(2), 119-129. https://doi.org/10.36497/jri.v40i2.101.

Hart, O. E., \& Halden, R. U. (2020). Computational analysis of SARS-CoV-2/COVID-19 surveillance by wastewater-based epidemiology locally and globally: Feasibility, economy, opportunities and $\begin{array}{lllll}\text { challenges. } & \text { Science } & \text { Thotal }\end{array}$ https://doi.org/10.1016/j.scitotenv.2020.138875.

Hongkong, H. (2017). Effect of Earnings per Share on Stock Prices. Journal of Accounting Vol 12. No.1. Jurnal Accountability, 6(2). https://doi.org/0.32400/ja.24807.6.2.2017.20-25.

Ibn-Mohammed, T., Mustapha, K. B., Godsell, J., Adamu, Z., \& Babatunde, K. A. (2021). A critical analysis of the impacts of COVID-19 on the global economy and ecosystems and opportunities for circular economy strategies. Resources, Conservation and Recycling, 164. https://doi.org/10.1016/j.resconrec.2020.105169.

Indayani, S., \& Hartono, B. (2020). Analisis Pengangguran dan Pertumbuhan Ekonomi sebagai Akibat Pandemi Covid-19. Jurnal Ekonomi Dan Manajemen Universitas Bina Sarana Informatika, 18(2). https://doi.org/10.31294/jp.v18i2.8581.

Jiang, X.-F., Xiong, L., Cen, T., Bai, L., Zhao, N., \& Zhang, J. (2021). Analyst sentiment and earning forecast bias in financial markets. Physica A: Statistical Mechanics and Its Applications. https://doi.org/10.1016/j.physa.2021.126601.

Kusuma, I. L. (2016). Pengaruh Asset Growth, Debt To Equity Ratio, Return On Equity, Total Asset Turnover Dan Earning Per Share Terhadap Beta Saham Pada Perusahaan Yang Masuk Dalam Kelompok Jakarta Islamic Index (Jii) Periode 2013-2015. Jurnal Riset Akuntansi Dan Keuangan, 4(2). https: //doi.org/10.17509/jrak.v4i2.4034.

Le, M., Hoang, V.-N., Wilson, C., \& Managi, S. (2020). Net stable funding ratio and profit efficiency of commercial banks in the US. Economic Analysis and Policy, 67. https://doi.org/10.1016/j.eap.2020.05.008.

Lubis, Z. A., Hutahaean, T. F., Kesuma, S., \& Karin, A. V. (2021). Pengaruh ROA, CR, dan DER terhadap harga saham perusahaan manufaktur subsektor food and beverage yang terdaftar di BEI Tahun 20152019. Jurnal Paradigma Ekomika, 16(3). https://doi.org/10.22437/jpe.v16i3.12664.

Luo, H. (2021). COVID-19 and trade credit speed of adjustment. Finance Research Letters, 9. https://doi.org/10.1016/j.frl.2021.102541.

Lyócsa, Š., Baumöhl, E., Výrost, T., \& Molnár, P. (2020). Fear of the coronavirus and the stock markets. Finance Research Letters, 36. https://doi.org/10.1016/j.frl.2020.101735.

Ma, C. (2020). Momentum and Reversion to Fundamentals: Are They Captured by Subjective Expectations of House Prices? Journal of Housing Economics, 49. https://doi.org/10.1016/j.jhe.2020.101687.

Maciel, L. (2021). A new approach to portfolio management in the Brazilian equity market: Does assets efficiency level improve performance? The Quarterly Review of Economics and Finance, 81. https://doi.org/10.1016/j.qref.2021.04.017.

Maulana, H. A. (2021). Psychological Impact of Online Learning during the COVID-19 Pandemic: A Case Study on Vocational Higher Education. Indonesian Journal of Learning Education and Counseling, 3(2), 130-139. https://doi.org/10.31960/ijolec.v3i2.833.

Paramita, I. B. G., \& Putra, I. G. G. P. A. (2020). New Normal Bagi Pariwisata Bali Di Masa Pandemi Covid 19. Jurnal Ilmiah Pariwisata Agama Dan Budaya, 5(2). https://doi.org/10.25078/pba.v5i2.1723.

Parlindungan, R., Sipahutar, \& Sanjaya, S. (2019). Pengaruh Current Ratio Dan Total Asset Turnover Terhadap Return On Assets Pada Perusahaan Restoran, Hotel Dan Pariwisata Yang Terdaftar Di Bursa Efek Indonesia. Jurnal Riset Akutansi Dan Bisnis, 19(2). https://doi.org/10.30596\%2Fjrab.v19i2.4753. 
Prawiyogi, A. G., Purwanugraha, A., Fakhry, G., \& Firmansyah, M. (2020). Efektifitas Pembelajaran Jarak Jauh Terhadap Pembelajaran Peserta didik di SDIT Purwakarta. JPD: Jurnal Pendidikan Dasar, 11(1). https://doi.org/10.21009/10.21009/JPD.081.

Rimbani, R. P. (2016). Analisis pengaruh roe, eps, pbv, der, dan npm terhadap harga saham pada perusahaan real estate dan property di bursa efek indonesia (bei) periode 2011 - 2013. Jurnal Bisnis Dan Manajemen, 53(12).

Sari, D. I. (2020). The Effect of Quick Ratio Total Asset Turnover and Return on Investment on Stock Prices. Journal of Accounting and Business, 5(2). https://doi.org/10.32502/jab.v5i2.2876.

Shah, K., Arfan, M., Mahariq, I., Ahmadian, A., Salahshour, S., \& Ferrara, M. (2020). Fractal-Fractional Mathematical Model Addressing the Situation of Corona Virus in Pakistan. Results in Physics, 19, 103560. https://doi.org/10.1016/j.rinp.2020.103560.

Sugiyono. (2019). Metode Penelitian dan Pengembangan (M. S. Sofia Yustiyani Suryandari, S.E. (ed.); 4th ed.). Alfabeta.

Tarkom, A. (2020). Impact of COVID-19 exposure on working capital management: The moderating effect of investment opportunities and government incentives. Finance Research Letters, 31. https://doi.org/10.1016/j.frl.2021.102666.

Wang, R. L., Shen, C.-L., Wu, T.-C., \& Hsiao, W. W.-W. (2021). A concise framework to facilitate open COVID pledge of non-disclosed technologies: In terms of non-disclosed patent applications and trade secrets. Journal of the Formosan Medical Association. https://doi.org/10.1016/j.jfma.2021.10.004.

Wei, Y., Qin, S., Li, X., Zhu, S., \& Wei, G. (2019). Oil price fluctuation, stock market and macroeconomic fundamentals: Evidence from China before and after the financial crisis. Finance Research Letters, 30. https://doi.org/10.1016/j.frl.2019.03.028.

Yulia, H. (2020). Online Learning to Prevent the Spread of Pandemic Corona Virus in Indonesia. ETERNAL (English Teaching Journal), 11(1). https://doi.org/10.26877/eternal.v11i1.6068.

Zheng, L., \& He, H. (2021). Share price prediction of aerospace relevant companies with recurrent neural networks based on PCA. Expert Systems with Applications, 183. https://doi.org/10.1016/j.eswa.2021.115384. 